\title{
A hostile world for nonhuman animals: human identification and the oppression of nonhuman animals for human goodi.
}

\section{Kay Peggs}

This is an accepted, postprint version of the published manuscript - Peggs, K (2009) A Hostile World for Nonhuman Animals: Human Identification and the Oppression of Nonhuman Animals for Human Good. Sociology 43 (1): 85-102.

\begin{abstract}
In 2006 over three million experiments were performed on nonhuman animals. In making an argument against such experiments I contend that approval of nonhuman animal experimentation is rooted in acceptance of humans as having essential primacy over nonhuman animals and lies in the power relations associated with human primacy identity claims. To challenge essentialist notions of human identity and human primacy I utilise a performative conceptualisation of identity. Discourses used by Pro-Test, a lobby that promotes nonhuman animal experimentation, allows an exploration of justifications made for animal experimentation. In promoting such experiments, I argue, Pro-Test is engaging in a form of human primacy identity politics based in continued inequality and the sustained oppression of nonhuman animals. I conclude that discourses extolling scientific advancements for human benefits, made on the basis of experiments on nonhuman animals, reiterate an immoral human primacy identity that dissolutely exploits power relations to privilege the human.
\end{abstract}

Keywords: animals, discourse, exploitation, human, identity, moral, performative, 'other', politics, primacy.

\section{Introduction}

In Britain in 20063.01 million 'procedures' were performed on nonhuman animals, an increase on the 2.9 million performed in 2005 (Pro-Test, 2007). In citing these Home Office figures, Pro-Test (2007) (a lobby launched in Britain in January 2006 to promote experiments $\mathrm{si}^{\mathrm{ii}}$ on nonhuman animals), declares that it 'welcome[s] statistics on animal research in 2006', even though the figures indicate an increase. How can Pro-Test take this position? In making an argument against such experimentation I contend that Pro-Test's position is based in the acceptance of 'human' as having primacy over 'animal' ${ }^{\text {iii, }}$, since Pro-Test grounds its case in the assumed pre-eminence of human needs over those of nonhuman animals. I maintain that assumed human primacy is used by Pro-Test as a justification for the exploitation of nonhuman animals for human benefit. My purpose is to draw attention to the ways in which Pro-Test seeks to validate experiments on nonhuman animals by using discourses that imply hierarchical differences between human and nonhuman animals that inform the 'in' identity of 'human' and the 'otherness' of all nonhuman animals. Following Jacques Derrida's claim that exclusionary identity is an act of power (Laclau 1990) I maintain that this is a form of human primacy identity politics, not 
based in overcoming oppression and inequality, but based in continued inequality and the sustained oppression of nonhuman animals.

Although organic differences exist among all animals (human and nonhuman), the 'key' division between human and nonhuman animals is founded in scientific categorizations of hierarchical differences that are a display of human identity since hierarchical distinctions between ' $u s^{\prime}$ and 'them' are founded in, I argue, judgments and choices rather than in naturally occurring scientifically verifiable hierarchical divisions. In this regard the conceptualisation of identity as performative (Butler 1999 ) is compelling since this stresses that 'our activities and practices...are not expressions of some prior identity...but are the very means by which we come to be what we are' (Loxley, 2007: 118). Thus I begin with an examination of identity and 'otherness' which allows me to explore notions of resemblance and difference and the ways in which nonhuman animals have been, and continue to be, seen by and treated by humans as excluded 'other'. The notion of identity as performative enables me to conceptualise human identity as a performative selectivity often defined politically through notions of human primacy over nonhuman animals. This leads me to contend that nonhuman animals are anthropolatrically ${ }^{\text {iv }}$ approved resources for actions that results in human gain, and such actions are based in power relations between human and nonhuman animals.

Human primacy discourses are fundamental to human primacy identity politics since such discourses influence perceptions of the relationship between human and nonhuman animals and reflect and reinforce any notions we might have of our own superiority. An analysis of statements made by Pro-Test (2006a, 2006b, 2006c, 2007) offers the opportunity to explore such discourses. By looking in detail at claims made by Pro-Test I conclude that discourses extolling scientific advancements that are founded in the exploitation of nonhuman animals for human benefit do not point to human moral progress, but rather are a reiteration of an immoral human primacy identity that dissolutely exploits power relations to privilege the human. I close by confronting the difficulties associated with conjoining a deconstructionist analysis of human identity with an argument in favour of a particular moral standpoint. Here I am guided by Zygmunt Bauman's (1993) contention that the very deconstruction of enlightenment certainties can itself lead to moral improvement.

\section{Identity and the other: the mark of nonhuman}

My aim in this section is to explore the concept of identity in relation to anthropolatrical conceptualisations of differences between humans and nonhuman animals, conceptualisations used to justify human gains achieved via nonhuman animal costs. Theoretical discussions about human identity in Sociology have moved away from conceptualisations of fixed identities to conceptualisations of new forms of deconstructed fragmented identification (Hall, 1996). For example Anthony Giddens argues that 'individuals tend to develop multiple selves in which there is no inner core of self identity' since we manipulate our conduct and our appearance in order to fit in with particular requirements and locales (1991: 100). Thus belonging is vital in identification. Individual self-identities are based in collectivities, for 
example at cultural, national and global levels, and here we might refer to collective social identities (eg based in gender, class or national identity), which provide frameworks of resemblance to and difference from other people (Jenkins 2004). Resemblance and difference have long been viewed as fundamental to conceptualisations of identification. In the seventeenth century John Locke argued that 'there is no point in asking for an account of identity by itself, but only for an account of what it is to be the same thing of a certain kind' (Noonan, 1998: 313). Still, Locke argued, resemblance functions simultaneously with difference since that which forms the identity of one sort of matter may be different from that which forms the identity of another sort of matter (Lowe, 1989: 2). Thus, as Stuart Hall pointed out much more recently, 'identities are constructed through, not outside, difference' (1996: 4), as a result, Hall continues, '...identities can function as points of identification and attachment only because of their capacity to exclude, to leave out, to render 'outside', abjected' (1996: 5, original emphasis). However, difference and resemblance are messy concepts in identification because the accomplishment of resemblance (and difference) relies in the discounting of some differences (and similarities). For example, identification (eg human) can be accomplished in recognition of 'significant' similarities (eg language use) and the discounting of differences judged less 'significant' (eg density of body hair). Moreover, differences (eg ability to fly unaided) among those designated as 'other' (eg nonhuman animals) are also diluted in the interests of the positing of the 'other' as excluded from 'us' (eg human). Drawing on the work of Jacques Derrida, Ernesto Laclau contends that it is through this exclusion of the 'other' that we can see that the 'constitution of identity is an act of power' (1990: 33). For Derrida, the foundation of identity is exclusion established in hierarchically defined binary oppositions (e.g. black/white, man/woman, human/animal, person/thing) (Laclau, 1990: 33). What is characteristic of the excluded second 'marked' term (e.g. black, woman, animal, thing) is that it is allocated to the subordinate limit of the 'violent hierarchy between the two resultant poles' (Laclau, 1990: 33). The marking of the term 'animal' at the subordinate pole is established in essentialist discourses about 'natural' divisions between 'them' and 'us,' positing distinctive essentialist identities that results not least in the assumed pre-eminence of 'our' needs over 'theirs', seen not least in the use of nonhuman animals in experiments for human benefit.

Essentialist assumptions have, of course, a very long history. In the seventeenth century the 'conceptual ground was...cleared to differentiate 'human' nature from 'animal' nature' (Anderson 1998: 30) via Rene Descartes notion that 'the mind is distinct from and superior to matter' (Sutcliffe, 1968: 19). Cartesian scientists accorded humans exclusive access to our conscious minds with nonhuman animals, in contrast, being declared incapable of thinking and hence incapable of feeling pain (Rowlands, 2002: 3). Although 'Descartes's naïve mechanistic belief that animals were actually unconscious... [has been] radically undermined by the advance of ethology' (Midgley, 2002 [1979]: 138), still concepts such as consciousness 'are often defined on the basis of what humans do' (Hauser, 2000: xviii). Accordingly power relationary subject positions between 'human' and 'animal' are made 'natural' via discourses about innate differences that obscure the centrality of power in hierarchical insider/outsider classifications and which mask the heterogeneity of the 
living. So although ' $\mathrm{t}$ ] here is no animal in the general singular, separated from man (sic) by a single indivisible limit' (Derrida, 2004: 125), in scientific and public discourses such identification is typically based in assumptions of natural differences that focus on the shared characteristics of designated groups. These discourses take for granted the view that the essentialist premise of the fundamental categorisation of human/animal is universal and natural, and in so doing obscure the social construction of the categorisation and the attendant power relations. But Derrida's comments draw us away from notions of essential differences to a conceptualisation of identity, to borrow Halls' terminology, as 'a construction, a process.' (1996: 2). This affords the capacity to focus on the social construction of rather than on any 'natural' disposition to specific identities and to centre on human and nonhuman animal identities as phenomena that are products of human power rather than as things that are predetermined.

Although change is fundamental to identification, Richard Jenkins' notion of 'primary identities' points to identities established in earlier life (e.g. humanness and gender) that are 'more robust and resilient to change later in life than other identities' (2004: 19). However, Judith Butler's (1999) notion of the 'performative subject' enables a querying of the claim that humanness is an essential primary identity, let alone a primacy identity. In holding that gender is 'performative' Butler (1999) counters the idea that there is something essential to gender identity. Thus 'what we take to be an internal essence of gender is manufactured through a sustained set of acts, posited through the gendered stylisation of the body' (1999: $\mathrm{xv}$ ). So, 'gender is not an expression of what one is; it is what one does' (Lloyd, 2005: 25 original emphasis). Consequently gender identity is always in process and it needs to be reiterated daily (Lloyd, 2005: 26). However, Butler does not deny that organic differences exist, but, in the case of sex differences, she asks, '...under what discursive and institutional conditions, do certain biological differences...become the salient characteristics of sex?' (Osborne and Segal, 1994: 36). I maintain that it is not only identities among humans that are performative, human identity is itself performative. Accordingly below I consider the discursive conditions und er which organic differences among animals are converted into the most significant features of the human/nonhuman animal divide, and how these features are used to promote the exploitation of nonhuman animals.

\section{Identity politics}

Organic differences exist among all animals but human identity assumptions are founded in a recognition of organic differences deemed most significant, that is those that underpin the binary hierarchical classification of all animals into 'human' and 'animal'. Like gender identities, species identities are performative selectivities, interpreted as natural, whereby the "merely different' is transformed into the 'absolute other' (Iris Young quoted in Lloyd 2005: 38). Accordingly, that which is presented as 'natural (or constative) [is] something that is a political effect (a performative) secured upon the field of power relations' (Lloyd, 2005: 39). 'So the identity 'woman' becomes political (becomes feminist) when an antagonism emerges with men or patriarchy' (Lloyd, 2005: 20). Following on from this I argue 
that the identity 'human' becomes a political identity (human primacy) when there is antagonism with nonhuman animal interests in anthropolatric society. However, there are important differences between identity politics and primacy identity politics. In identity politics the goal is usually 'the call to 'respect' traditionally disadvantaged social groups' (Fuller, 2006: 111-2) whereas the goal in primacy identity politics is the preservation or extension of existing power relations through the continued subjugation of disadvantaged groups. In identity politics the lack of a conception of a stable identity (eg what women share), means that, for many feminists, such politics (eg the goal of women's liberation) is unworkable (Lloyd, 2005:13). I maintain that in the case of primacy identity politics there are considerable emancipatory possibilities associated with viewing identities as destabilised. Thus Moya Lloyd's contention that the goal of identity politics can be strengthened by a focus on the performative nature of identity is also persuasive for challenging exploitation fundamental to primacy identity politics, since such a focus 'facilitates an understanding of how particular identity claims have been (and may continue to be) made' (2005: 30). How has human primacy identity been claimed? Jenkins holds that '[c]ollective identities are usually located within territories or regions' (2004: 26) and, I contend, the collective identity 'human primacy' is forged within the virtual territory of human superiority and the actual region of human power. Discourse is central to power relations since discourses based in the actual zone of human power facilitate the persistence of the virtual zone of human superiority which preserves human exploitation of nonhuman animals.

Discourse is central to our construction of 'reality' since 'linguistic acts don't simply reflect a world ... [they] actually have the power to make a world' (Jackson 2004). For example, Lloyd explains that 'every time we state our sex as female on a form...' (2005: 26) we are reiterated as female. But, of course, it is not simply through discourses that performative identities are shaped since 'norms, power relations, institutions and practices' (Lloyd, 2005: 27) are also crucial, however, it is the 'reiterative power of discourse to produce the phenomena that it regulates and constrains' (Butler, 1999: 2). Michel Foucault's study of governmentality points to the ways in which discourses are influential in constructing seemingly essential identities. His historical study shows 'how effects of truth are produced within discourses which in themselves are neither true nor false' (Gordon, 1980: 118). Truth-promoting discourses influence our perceptions of, for example, the relationship between humans and nonhuman animals and reflect and reinforce our notions of our own transcendence. Nevertheless, if nonhuman animals are no longer perceived by humans to be lacking in thought and sensation, as they were by Cartesian scientists, how can humans accept, and even promote, experiments on nonhuman animals? Carol, J. Adams argues that our language is structured to convey such acceptance (1990: 66). Below I examine discourses used by Pro-Test to promote nonhuman animal experimentation which, I argue, reiterate human primacy assumptions and thus acceptance of such experimentation.

\section{A hostile world for nonhuman animals: the primacy identity politics of Pro-Test}


The campaign group Pro-Test was launched with the stated aim of countering antivivisectionist campaign groups that sought to halt the construction of the new Biomedical Research Facility at the University of Oxford (Boggan, 2006). Pro-Test's website campaign material (2006a, 2006b, 2006c, 2007) provides the opportunity to explore how this political group reiterates human primacy identity through the justification of experimentation on nonhuman animals. Below I examine Pro-Test's stated aims and study key claims; about science, about the caring community of scientists, about similarities and differences between human and nonhuman animals, and about the scientific and moral 'necessity' of experimentation on nonhuman animals as a mechanism of human advancement.

\section{The Pro-Test campaign}

\section{The stated aims of Pro-Test are}

'...to counter the irrational arguments of anti-vivisectionists by raising public awareness of the benefits of animal research and creating an environment where scientists can speak out about their work and be proud of the contributions they make. We stand for science, reasoned debate and, above all, the promotion of the welfare of mankind. Pro-Test exists to support the construction of the Oxford lab, to make the case for animal research, and more generally to defend scientific research as a necessary tool of human progress in a climate that is increasingly misanthropic and suspicious of scientists. We support only non-violent protest and condemn those using violence or intimidation to further their goals. We strongly support animal testing as crucially necessary to further medical science' (2006a)

Lloyd remarks that 'without a shared experience of - an identity - political demands cannot be articulated in the first place' (2005: 55-6). In the context of this paper I reshape this to without a shared experience of and acceptance of 'supremacy'-a primacy identity - Pro-Test could not begin to articulate political demands based in the acceptable exploitation and death of nonhuman animals. Accordingly, for ProTest, experiments on nonhuman animals are justifiable on the grounds that they are 'crucially necessary' for the 'welfare' of humans. To be sure, humans have interests but, of course, nonhuman animals have interests as well. As conscious sentient beings, nonhuman animals have desires and preferences (Rowlands, 2002: 23), but they are treated as 'acceptable losses' (Rowlands, 2002: 212) since '[e]ven if we think that animals can suffer pain, and even death, but humans can suffer more, in the event of a conflict of interests, we would be justified in choosing to sacrifice the interests of animals' (Garner, 2005: 23). So the identity 'human' becomes a political identity (human primacy) because antagonism has emerged about nonhuman animal interests in anthropolatric society. I argue that in the interests of human primacy, Pro-Test makes a number of claims (considered below) in promotion of nonhuman animal experimentation. Via these claims Pro-Test seeks to preserve a 'socioethical domain' (Michael and Birke, 1994: 189) in an effort to discursively shield vivisectionists from condemnation (eg in claims about 'the promotion of the welfare of mankind') while at the same time problematizing disapproval of nonhuman 
animal experimentation (eg in claims about 'the irrational arguments of antivivisectionists').

\section{The claim that 'we stand for science'}

Beth Humphries argues that the driving force of knowledge produced by scientists is 'ownership by a privileged research community in the interests of dominant groups' (2000: 187). In the case of nonhuman animal experimentation Pro-Test explicitly announces its support for such experiments on the grounds of human benefits. So Pro-Test (2006b) declares that 'animal testing is a necessary stage in the development of new cures, therapies and procedures designed to cure illnesses, save lives and improve the quality of human life'. Conservative estimates indicate that well over 100 million nonhuman animals worldwide are used in experiments every year (Rowlands, 2002: 124) and the research typically intrudes on the physical body of a nonhuman animal, causing the pain and suffering that is ' often an inherent part of scientific procedures without which the work would not have a chance of achieving its objectives' (Rowlands 2005: 121). However, the utility to humans of nonhuman animal experimentation is open to question. Although ProTest (2006a) asserts that, '[w]e strongly support animal testing as crucially necessary to further medical science' the necessity of nonhuman animal experimentation in medical research is contentious since there is disagreement among scientists about whether such experiments promote human benefits. For example, the UK medical research charity the Dr Hadwen Trust notes 'serious scientific limitations' (2006: 3) with nonhuman animal experiments ${ }^{\mathrm{v}}$ and concludes that ' $[\mathrm{w}]$ ith animal experiments providing unreliable and potentially misleading results, it is irresponsible to portray animal research in general as a 'gold standard' (2006: 4). Although it is undeniable that many scientists support nonhuman animal experimentation Mark Rowlands affirms that numerous scientists do not because much of the research is marginal to human interests, is ineffective, and much of the knowledge gained is either already available or is obtainable via other means (2002: 150-151).

Even if some nonhuman animal experiments are necessary for the promotion of human vital interests, such research would be seen as morally repugnant if it were not for notions of human primacy. Taking into account the problems with nonhuman animal experiments it could be argued that experiments upon humans would be more effective in respect of human utility (Sztybel 2006: 174). Of course, experimenting on humans who are unable or unwilling to give their consent would be morally repugnant, and I would not wish to give such a course of action any moral sanction. However, the promotion of conceivably less beneficial and possibly detrimental nonhuman animal experiments over more beneficial and valuable human experiments emphasizes that human primacy is central to the implementation of nonhuman animal experimentation. Most obviously, scientific experiments could not be performed on non-consenting nonhuman animals without the assumption of the primacy of those in whose name the experiments are performed since it is accepted that it would be highly immoral to carry out such experiments on non-consenting humans. Thus experiments on nonhuman animals 'can only be sustained because animals are regarded as expendable slaves, because 
their suffering is not fairly considered (Sztybel 2006: 188). Consequently, Adams reflects, 'animal experimentation seems less a scientific question than a power issue' since it is 'disenfranchised bodies' that are used to increase scientific knowledge (1995: 138). Thus, nonhuman animal experimentation, whether necessary or not for nonhuman benefits, reiterates human primacy.

\section{The claim that experiments on nonhuman animals lead to 'the promotion of the welfare of mankind'}

The 'vast industry of animal experimentation' (Singer, 1990: 87) in Britain is regulated by the 1986 Animals (Scientific Procedures) Act which incorporates a 'costbenefit clause whereby potential benefits of the procedures are weighed up against the suffering intended to be inflicted' (Garner, 2005: 125). The purpose of much experimentation is, however, to 'inflict pain and suffering on animals' (Garner, 2005: 121). In promoting nonhuman animal experimentation Pro-Test must engage with moral dispute $\mathrm{e}^{\mathrm{vi}}$ and in order to defend their position they are compelled, I argue, to depend on human primacy, where the suffering inflicted on nonhuman animals is viewed as 'justified morally if it serves a necessary human purpose' (Garner, 2005: 125). It might be argued that Pro-Test's contention that '[a]nimal welfare must be taken into consideration, but ultimately, human beings must come first' (2006a) is consistent purely with a moral obligation to the human species vii (eg Williams 2006) rather than with affirming human primacy. However, I maintain that the moral obligation position reflects rather than contradicts human primacy notions by relying on speciesist assumptions that conform with, to use Peter Singer's words, the 'conventional assumption that we are, simply because we are human, justified in overriding the interests of nonhuman animals when they conflict with our own' (2002: 3). Accordingly, the moral obligation position reiterates human primacy. In this regard Pro-Test asserts that,

' $[t]$ he cost in animal lives of the life-saving research carried out using animals is less than 3 animals per person in the UK over the course of that person's lifetime (under 3 million animals per year are used per year, over $90 \%$ of them animal rodents). Anyone who thinks a human life or the alleviation of human suffering is not worth the life of 3 rats has a deeply degraded view of the value of human life and well-being' (2006b: 3-4, original emphasis)

Pro-Test implies that it is self-evident that the welfare of a human is worth the suffering and death of three nonhuman animals, especially rats 'whose public image has of course been largely formed by their long history not as pets but as pests' (Midgley, 2004: 148-9). In a laboratory setting the rat is viewed as 'a piece of laboratory equipment with the function of being used to test hypotheses, a kind of purpose-made flesh-and-blood robot' (Midgley, 2004: 149). Thus human primacy politics awards humans a superior place in a human-constructed order, an order that classifies nonhuman animals as resources (Rowlands, 2002: 196) and in so doing evaluates them in terms of their utility (and nuisance) to humans. The rat is at once classified as a 'nuisance' and 'useful'; s/he is especially utilisable and expendable precisely because rats are classified as vermin. The promotion of nonhuman animal 
experimentation can be contrasted with political campaigns against, for example, the use of human embryos in research (eg evidenced in alarm about research on

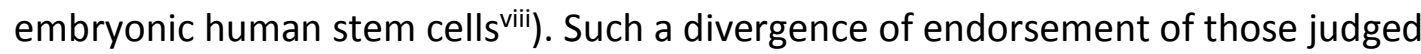
to be acceptable and unacceptable for human welfare scientific experimentation lays bare the real power relations that are founded in virtual human primacy. As Rowlands argues, even if some research on nonhuman animals is necessary for the promotion of human vital interests such research is illegitimate since it rides roughshod over the autonomy of nonhuman animals (2002: 147) by curtailing their ability to do what they want to do in the favour of how humans want to use them.

\section{Claims about the differences yet similarities between human and nonhuman animals}

Although experimentation on nonhuman animals is founded in assumptions about the otherness of nonhuman animals, the suggestion that the differences are too great, thereby making experiments on nonhuman animals specious ${ }^{i x}$, is dismissed by Pro-Test.

'Animal models are not perfect representations of humans and scientists are well aware of this. But, they do serve as excellent substitutes (mostly using mice, rats and other small rodents) for humans. As the genomic revolution has come around and the genomes of both humans and animals have been sequenced, we have realized that there are much more similarities between humans and animals than there are differences. It has also enabled us to identify where humans and particular animals are identical, as some animals serve as accurate representatives of a human's anatomy, while others may share identical biochemical pathways. Genomic knowledge has made it so that animal research can be much more specifically targeted and accurate when representing a human, thus correctly predicting a (sic) how a human will react... Mice are actually considered the best model of inherited human diseases. This is because they share $99 \%$ of all the genes with humans!' (2006b: 2)

The plea is to difference yet similarity. The plea to difference is implicit and elemental to Pro-Test's claims since without difference human benefit reasons for nonhuman animal experiments would be morally objectionable. As we have seen, to experiment on those like us (ie humans) would be seen as morally repugnant without their consent. The plea to similarity is explicit and also fundamental to ProTest's claims since without similarities nonhuman animal experimentation would be deemed to be pointless. So, differences are deemed to be sufficiently significant to permit experimentation on nonhuman animals on moral grounds, yet similarities are deemed to be adequately apparent to make experiments useful on human benefit grounds. Adams notes that this two-sided 'formula for knowledge' is based in the notion that 'animals are not like us so we can... animals are like us so we conclude...'(1995: 52). Adams (1995) proposes that this confirms that arguments that promote animal experimentation are grounded in relations of power rather than in organic similarities and differences, which are open to question and 
manipulation. Indeed the possibilities associated with genetic modification, implies Pro-Test, means that differences can be reduced. Pro-Test claims that mice 'are actually considered the best model of inherited human diseases. This is because they share $99 \%$ of all the genes with humans!'(2006b: 2$)^{\mathrm{x}}$ and Pro-Test (2007) later declares that 'GM animals, mainly mice, can offer better animal models for human diseases....'. If organic differences can be manipulated and reduced ${ }^{\mathrm{xi}}$, justifications made by those who promote experiments on nonhuman animals on the basis of human primacy and human/nonhuman animal differences become increasingly insupportable.

\section{The claim that 'scientists and their lab technicians care deeply about the welfare of the animals'}

Rowlands observes that, as a nonhuman animal in the seventeenth or eighteenth centuries 'one of the things you should have made a point of avoiding would be Cartesian scientists. If not, then you could expect to find yourself nailed to a vivisection board being slowly cut open. You would be conscious throughout' (2002: 3). Although human knowledge about nonhuman animals has advanced since Cartesian times as 'modernism has...refused the Cartesianism that denied animals affectivity, sentience, and intelligence' (Emel and Woolch, 1998: 20), Rowlands warns, '...our present day treatment of many animals is no better than that of the Cartesian scientists....in some respects we are much worse...[a]t least, they thought that animals were incapable of suffering' (2002: 5). Although the 'moral orthodoxy'xii requires that 'animal experimentation is justified morally if the suffering inflicted on animals serves a necessary human purpose' (Garner, 2005: 125), suffering is widespread in nonhuman animal experimentation today. Yet, the 'thin veneer of civility surrounding human-animal relations' (Wolch and Emel, 1998: xi) makes much of the developments made in laboratories in Britain. Robert Garner maintains that 'The British legislative framework actually goes further than the moral orthodoxy prescribes.... whereby an experiment must stop - irrespective of the consequences for the research - if the suffering inflicted exceeds what is allowed for in the licence' (2005: 124) and Baruch, A. Brody reports that researchers are obliged to use sedation and anaesthesia where appropriate and to 'kill animals painlessly after experiences when the animals would otherwise [suffer]' (2001). It is not my intention here to assess the degree of suffering caused ${ }^{\text {xiii }}$, because it is the premise that nonhuman animals can be experimented upon that is my focus. Nevertheless, the degree of suffering is a significant element of the discursive shield used by ProTest. The group confidently claims that ' $[t]$ he UK has one of the tightest systems of regulation in the world, with over 2,000 inspections annually, most of them surprise inspections' (2006b: 3). Mike Michael and Linda Birke note that in their interviews with scientists '...it seemed important to our respondents to convey a belief that British animal experimentation is part of a tradition that has directed much effort and many resources to the care of animals' (1994: 195). Pro-Test further claims that concerns about nonhuman animal welfare in laboratories have not only emerged from British legal compulsion since, 
'...scientists and their lab technicians care deeply about the welfare of the animals they work with and are often animal lovers themselves... Wherever possible, animals are anaesthetised during testing, meaning they feel no pain, while operations are carried out under the same sterile and aseptic conditions you would expect in any hospital where humans are treated' (2006b: 3).

An important element of the discursive shield depicts the experimenters as caring humans undertaking vital research in the most sensitive of ways rather than as causing the suffering of sentient creatures. In their research Michael and Birke noted that scientists analysed their involvement in nonhuman animal experimentation in terms of a "process of self-definition through comparison and differentiation from a group of 'others" (1994: 191). Accordingly scientists distinguish themselves from others to 'present their own practices of animal experimentation in a positive moral light' (Michael and Birke, 1994: 191). So, although scientists embrace notions of value freedom, here we are assured that scientists have feelings. Of course they do, but any feelings provoked by nonhuman animal suffering in such experiments are secondary in a science that constructs human needs as pre-eminent. Pro-Test presents the relationship between key laboratory personnel (the experimenters) and nonhuman animals (the experimented upon) as like a partnership; these humans work 'with' rather than 'on' nonhuman animals, conceivably implying that nonhuman animals and humans are working together for the benefit of humans. Moreover, Pro-Test asserts that experiments on nonhuman animals are undertaken under the same conditions as the treatment of humans. Such analogies are intended to assuage any guilt that humans, the instigators and beneficiaries of the suffering, might feel. Furthermore relations of compassion that focus on caring humans are an essential part of human primacy notions of the superior civilized human consciousness. In this case this human sense of advanced human morality nevertheless confirms human notions of the preeminence of human needs.

\section{The claim that experimentation on nonhuman animals is 'a necessary tool of human progress'}

Pro-Test (2006a) 'defend[s] scientific research as a necessary tool of human progress'. Hence, for Pro-Test, human progress appears to be measured in terms of scientific 'advancement' designed to satiate human interests. Pro-Test is, of course, not alone. The group reports that 'The House of Lords Select Committee, the Parliamentary Animal Procedures Committee and the independent Nuffield Council on Bioethics all concluded that testing on animals is a scientifically sound method, has yielded great results in the past, and is crucial for future advances.' (2006c: 1). Such advances are based in value judgements founded in the interests of humans since '[g]enerally, animals are part of the stories of progress, rationality, economic growth, and emancipation only by their eradication, sacrifices, bred domesticity, and genetic transfiguration' (Emel and Woolch, 1998: 20). An equation of human advancement with human progress relies on a straightforward notion of the meaning of progress. John Gray's understanding is much more complex since 
' $\mathrm{s}$ ]cience enables humans to satisfy their needs.... [t] here is progress in knowledge, but not in ethics' (2002: 155) and for Hans Jonas, as Bauman notes, 'our moral sensitivity has hardly progressed since the time of Adam and Eve' (2006: 91). Nonhuman animals are placed outside of, what William Lynn terms, the 'moral community' of humanity and 'this justifies the most brutal and exploitative of power relations' (1998: 286). But, as Jane Tomkins comments, 'to see animals differently would require human beings to see themselves differently' (quoted in Adams, 1995: 12), and Pro-Test is plainly anxious about the effects of such a change. Their claim that we live in a 'climate that is increasingly misanthropic' is the kind of protestation raised by those whom Lynn (1998) calls 'species loyalists' who 'worry that we lose our moral concern for humans when we become concerned about animals' (1998: 287). However, as Lynn asserts, there is no reason to correlate concerns about nonhuman animals with lack of concern for humans and 'if we wish to live morally in concert with a diversity of human and nonhuman animals we must adjust our... interactions accordingly' (1998: 295).

\section{Conclusion}

In this paper I have argued that Pro-Test's endorsement of nonhuman animal experimentation is a display of human identity based in assumptions of natural hierarchical differences established in distinctions entrenched in human/nonhuman animal power relations. I have maintained that Pro-Test's support for nonhuman animal experimentation is a political expression of human identity; that is human primacy identity. Such expressions are founded in claims of essential characteristics of species distinctiveness that locate nonhuman animals as 'other' than human, but I contend are founded in discourses that construct 'truths' about human identity. These discourses are based in human conceptualisations and relational categorisations where nonhuman animals are grouped collectively as essentially inferior 'other' and where humans are conceptualised as transcendent 'us'. The focus on discourses used by Pro-Test has afforded an examination of justifications made for experiments on nonhuman animals. Pro-Test's reasoning is grounded in a mission of human gain based in assumptions about indispensable scientific advancements made through nonhuman animal experimentation, about concern for the welfare of nonhuman animals when these do not conflict with the needs of humans, about the similarities and differences between human and nonhuman animals which make experiments at the same time morally acceptable and beneficial and about the moral principles they associate with their aims and claims. However, I have argued that such justifications are rooted in the fundamental tenet of the human identity as transcendent.

I have maintained that a performative conceptualisation of identity challenges such essentialist notions of human identity and attendant perceptions of primacy. This has enabled an exploration of the methods by which human primacy identity claims have been made and has facilitated an exploration of how human transcendence is founded in and reiterative of a constructed human primacy rather than in a confirmed essential human supremacy. Although organic differences exist, the differences among nonhuman animals are certainly as extensive as the differences 
between human and nonhuman animals. So organic differences do not provide good reason for the continuation of experimentation on nonhuman animals; indeed it is organic similarities that are often used in justification of such experimentation. Rather, it is differences in power that are, I have argued, at the root of experimentation on nonhuman animals, a power embraced by human primacy identity politics, a politics that supports and promotes human assumptions of our own superiority. Such human primacy identity assumptions enable the disenfranchised bodies of nonhuman animals to be abused in the interests of scientific 'progress'. For Pro-Test scientific progress is synonymous with human progress, but I have argued, this conceptualisation is forged within the virtual region of human superiority and actual region of human power.

There are considerable difficulties associated with conjoining a deconstructionist analysis of human identity with a moral standpoint against nonhuman animal experimentation, since deconstructionist accounts are associated with an 'emancipation' from moral standards (Bauman, 1993:) not least because deconstructionists argue that since 'ethics is contextual' there are no firm grounds for any particular ethical belief' (Crawford, 1998: 121). However, Bauman, argues against an 'overtly relativistic and in the end nihilistic view of morality' (1993: 12). For Bauman (1993), it is the very certainties associated with modernity that have obstructed self-reflection Thus, if we conceive of identity as essential 'our points of view will be narrow and our interests narrowly conceived' (Crawford, 1998: 130131). But if we move away from formulating 'human' as, in Colin Philo's terms, 'the chief point of reference' (1998: 54), the very frustration of the certainties associated with modernity, for example the deconstruction of enlightenment certainties of self and the other, can lead to moral improvement (Bauman 1993: 14). So deconstructionism can lead to the exposure of fissures in modernist assumptions, which has enabled questioning of modernist certainties about, for example, the other and the position of the other. For Bauman 'a postmodern ethics would be one that readmits the Other as a neighbour...back from the wasteland of calculated interests to which it had been exiled...an ethics that recasts the Other as the crucial character in the process through which the moral self comes into its own' (1993: 84). It is when we 'accord the Other that priority which was once unquestionably assigned to the self' (Bauman 1993: 85) that our moral lives may be enhanced. Mohandas K. Gandhi stated that 'The greatness of a nation and its moral progress can be judged on the way its animals are treated' (Hanru, 2006: 2). This proclamation may be often quoted but that does not detract from its significance. If we recast the other and live morally in concord with nonhuman animals rather than promote our notions of our own primacy, we humans could do much good as 'the practice of moral concern across a range of beings and issues may strengthen our ethical insights and commitments' (Lynn 1998: 288).

\section{Acknowledgements}

My thanks to the two anonymous referees for their insightful and helpful comments.

\section{References}


Adams, C. J. (1990). The Sexual Politics of Meat. Cambridge: Polity Press.

Adams, C. J. (1995). Neither Man nor Beast: Feminism and the Defense of Animals. New York: Continuum.

Anderson, K. (1998). 'Animals, Science, and Spectacle in the City', in J. Wolch and J. Emel (eds) Animal Geographies: Place, Politics and Identity in the NatureCulture Borderlands. Pp. 27-50. London and New York: Verso.

Bauman, Z. (1993). Postmodern Ethics. Oxford: Blackwell

Bauman, Z. (2006). Liquid Fear. Cambridge: Polity Press.

Boggan, S. (2006). 'Experiments in protest', The Guardian G2, 03 March

Brody, B. A. (2001). 'Defending Animal Research: An International Perspective', in E. F. Paul and J. Paul (eds) Why Animal Experimentation Matters: The Use of Animals in Medical Research, pp. 131-147. New Brunswick, NJ: Transaction Publishers and the Social Philosophy and Policy Foundation.

Butler, J. (1999) Gender Trouble, 2nd edn. London: Routledge

Campaign Life Coalition (2006) Experimentation on Human Embryos Stalled: Media release 24 April 2006, URL (consulted June 2007) http://www.lifesite.net.

Campbell, D. (2007). 'Confused by health advice? Then read on', The Observer 05 August.

Chambers (1993). The Chambers Dictionary. Edinburgh: Chambers Harrap.

Crawford, N. (1998) 'Postmodern Ethical Conditions and a Critical Response', Ethics and International Affairs 12 (1):121-140.

Derrida, J. (2004), 'The Animal That Therefore I am (More to Follow)', in P. Atterton and M. Calarco (eds) Animal Philosophy: Essential Readings in Continental Thought, pp. 113-128. London and New York: Continuum

Dr Hadwen Trust (2006) About Us, URL (consulted Aug. 2007): http://www.drhadwentrust.org/about-us/about-us.

Emel, J. and Wolch, J. (1998). 'Witnessing the Animal Moment', in J. Wolch and J. Emel (eds) Animal Geographies: Place, Politics and Identity in the NatureCulture Borderlands, pp 1-24. London and New York: Verso.

Fuller, S. (2006). The New Sociological Imagination. London: Sage.

Garner, R. (2005). Animal Ethics. Cambridge: Polity Press.

Giddens, A. (1991). Modernity and Self-identity. Cambridge: Polity Press.

Gordon, C. (1980), (ed) Michel Foucault Power/Knowledge: Selected Interviews and Other Writings 1972-177 by Michel Foucault, Trans. C. Gordon, L Marshall, J. Mepham and K. Soper. London: Harvester Wheatsheaf.

Gray, J. (2003). Straw Dogs: Thoughts on Humans and Other Animals. London: Granta.

Hall, S. (1996) 'Introduction: Who Needs Identity?', in S. Hall and P. du Gay (eds) Questions of Cultural Identity, pp1-19. London: Sage.

Hanru, Z. (2006). 'Treat animals right to prove yourself', The China Daily 18 August URL (consulted Aug 2007): http://www.chinadaily.com.cn/200608/18/content_667769.htm.

Hauser, M. (2000). Wild Minds: What Animals Really Think. London: Allen Lane The Penguin Press

Humphries, B. (2000). 'From critical thought to emancipatory action: contradictory research goals', in C. Truman, D. M. Mertens and B. Humphries (eds)

Research and Inequality, pp 179-190, London: UCL Press. 
Jackson, S. (2004). Professing Performance: Theatre in the Academy from Philology to Performativity. Cambridge: Cambridge University Press.

Jenkins, R. (2004) Social Identity, $2^{\text {nd }}$ edn. London and New York: Routledge.

Laclau, E. (1990) New Reflections on the Revolution of Our Time, London: Verso.

Lloyd, M. (2005) beyond identity politics: feminism, power and politics. London: Sage. Lowe, E. J. (1989). 'What is a Criterion of Identity?', The Philosophical Quarterly 39 (154): 1-21.

Loxley, J. (2007). Performativity. London: Routledge.

Lynn, W. S. (1998). 'Animals, Ethics and Geography'. In J. Wolch and J. Emel (eds) Animal Geographies: Place, Politics and Identity in the Nature-Culture Borderlands, pp 280-297. London and New York: Verso.

Michael, M. and Birke, L. (1994). 'Accounting for Animal Experiments: Identity and Disreputable "Others"', Science, Technology and Human Values 19 (2): 189204.

Midgley, M. (2002 [1979]). Beast and Man, London: Routledge.

Midgley, M. (2004) The Myths We Live By, London: Routledge.

Noonan, H. W. (1998). 'Animalism versus Lockeanism: A current controversy', The Philosophical Quarterly 48 (192): 302-318

Osborne, P. and Segal, L. (1994). 'Gender as Performance: an interview with Judith Butler', Radical Philosophy 67:32-9

Philo, C. (1998). 'Animals, geography, and the City: Notes on Inclusions and Exclusions' in J. Wolch and J. Emel (eds) Animal Geographies: Place, Politics and Identity in the Nature-Culture Borderlands, pp 51-71. London and New York: Verso.

Pro-Test. (2006a). 'About us', Pro-Test: standing up for science, URL (consulted Aug. 2007): http://www.Pro-Test.org.uk/about.php.

Pro-Test. (2006b). 'Frequently Asked Questions', Pro-Test: standing up for science, URL (consulted Aug. 2007): http://www.Pro-Test.org.uk/facts.php?It=b. pp14

Pro-Test. (2006c). 'Benefits', Pro-Test: standing up for science, URL (consulted Aug. 2007):http://www.Pro-Test.org.uk/facts.php?lt=b. pp1-2.

Pro-Test. (2006d). 'Ethics', Pro-Test: standing up for science, URL (consulted Aug. 2007) :http://www.Pro-Test.org.uk/facts.php?lt=a.

Pro-Test. (2006e). 'About The Research', Pro-Test: standing up for science, URL (consulted Aug. 2007): http://www.pro-test.org.uk/facts.php?lt=d

Pro-Test. (2007). 'Latest News: Pro-Test welcomes Home office statistics on animal research for 2006', Pro-Test: standing up for science, URL (consulted Jul. 2007): http://www.Pro-Test.org.uk.

Randerson, J, (2007) 'Government downplayed animal suffering in experiments', The Guardian 28 July.

Rowlands, M. (2002). Animals Like Us. London: Verso.

Singer, Peter (1990) Animal Liberation, $2^{\text {nd }}$ edn. London: Cape.

Singer, P. (2002) Unsanctifying Human Life. Ed H. Kuhse. Oxford and Malden MA: Blackwell

Sutcliffe, F. E. (1968). 'Introduction', In R. Descartes. Discourse on Method and Other Writings, pp 7-23. Middlesex: Penguin. 
Szytybel, D. (2006) 'A Living Will Clause for Supporters of Animal Experimentation'. Journal of Applied Philosophy 23 (2): 173-189

Williams, B. (2006) Philosophy as a Humanistic. Princetown , Princetown University Press

Wolch, J. and Emel, J. (1998) 'Preface', in J. Wolch and J. Emel (eds) Animal Geographies: Place, Politics and Identity in the Nature-Culture Borderlands, Pp xi-xx. London and New York: Verso.

\section{Notes}

'I do not explore connections between 'systems of domination' (eg how male white supremacy pervades the lives of Black people, women and nonhuman animals) (see Adams 1990, 1995).

ii Pro-Test promotes experiments for 'pure research' (eg how the brain works), for 'applied research' (eg cures for diseases), and for 'toxicology research' (testing substances for lethal effects) (Pro-Test 2006e).

iii The term 'animal' is rarely used for humans except with negative connotations (Adams 1990).

iv I use 'anthropolatric' (human worship) rather than 'anthropocentric' (human as centre of the universe) (Chambers 1993) as this term better characterizes human primacy.

$\checkmark$ The problems with using nonhuman animals as 'models' for human illnesses and concerns is highlighted in the near deaths of six human volunteers in the TGN 1412 trial in 2006 (Dr Hadwen Trust 2006: 5)

vi Pro-Test's 'Ethics' web page merely states 'a section of ethics' (2006d)

vii I am grateful to an anonymous reviewer for making this point.

viii For example the President of the Campaign Life Coalition (based in Canada) states that 'The callous disregard for human life is so obvious in the use of embryos for research' (Campaign Life Coalition 2006:1)

${ }^{i x}$ Eg the Dr Hadwen Trust argues that '[a]nimal studies offer the advantage of researching a whole organism, but for medical research they are simply the wrong organisms' (2006: 4)

${ }^{x}$ However, it seems that some scientists are cautious about the ultimate scientific effectiveness of using mice. In response to experiments on nonhuman animals that revealed that coffee might prevent skin cancer Dr Alison Ross, a science information officer for Cancer Research UK, advises 'caution' since ' $[\mathrm{t}] \mathrm{his}$ study was carried out in mice, so we need more research' (Campbell 2007: 15).

xi Lack of space precludes discussion of the moral issues associated with genetic modification.

xii Garner notes that the 'moral orthodoxy' is the prevailing attitude that nonhuman animals have some moral status but that humans are more important (2005: 15). xiii However, press reports claim that a high court judge has proclaimed that the British government 'has downplayed the suffering experienced by some animals used in experiments by incorrectly applying the law' (Randerson 2007). 